\title{
Green Urbanism Incorporating Greenery-Based Conceptual Model towards Attaining a Sustainable Healthy Livable Environment—Dhaka City's Perspective
}

\author{
Meher Nigar Neema ${ }^{1}$, Khandoker Md. Maniruzzaman², Akira Ohgai $^{3}$ \\ ${ }^{1}$ Department of Urban and Regional Planning, \\ Bangladesh University of Engineering and Technology, Dhaka, Bangladesh \\ ${ }^{2}$ Department of Urban and Regional Planning, College of Architecture Planning, \\ University of Dammam, Dammam, KSA \\ ${ }^{3}$ Urban and Regional Planning Division, Department of Architecture and Civil Engineering, \\ Toyohashi University of Technology, Toyohashi, Japan \\ Email: mehernigar@urp.buet.ac.bd
}

Received May 30 ${ }^{\text {th }}, 2013$; revised July $2^{\text {nd }}, 2013$; accepted July $22^{\text {nd }}$, 2013

\begin{abstract}
Copyright (c) 2013 Meher Nigar Neema et al. This is an open access article distributed under the Creative Commons Attribution License, which permits unrestricted use, distribution, and reproduction in any medium, provided the original work is properly cited.
\end{abstract}

\begin{abstract}
In this paper, a model of green urbanism (GU) incorporating the concept of planting trees and greeneries has been proposed. The GU model attempts to address challenges encountered by dynamically changing cities around the globe due to the increasing events of urban greeneries transforming into built-up areas. A framework is designed to develop a greenery-based conceptual model (GBCM) towards attaining a sustainable healthy livable (SHL) environment. The model is applied to mega city Dhaka as a case study considering its adopted greenery-based urban strategies and methodologies to deal with both social and economic aspects. In this context, we first revisit the present state-of-the-art of greeneries in Dhaka, then examine whether Dhaka is a SHL-city and finally, an attempt has been taken to revive Dhaka as GU to bring a sustainable healthy environment. The model has confirmed that greenery is the prime factor of green urbanism which could bring a number of fundamental environmental benefits such as reduction in energy use, pollution, waste generation, emission of greenhouse gas, impacts on climate and occurrence of natural disasters. The model thus developed has an implication on how city planners can adapt a priori approach to ensure sustainable health of populations combating unprecedented social, economic and environmental challenges of unsustainable, unhealthy, and unlivable (3U) cities due to insufficient greeneries.
\end{abstract}

Keywords: Green Urbanism; Healthy City; Livable City; Sustainable City; Greenery; Tree

\section{Introduction}

Aristotle coined the term cities as places where people come together to enjoy good life. Cities around the globe are manifested with much denser population distributions and intensive human activities. Typically cities possess a hypothetical "metabolism" system which has input and output related to solid waste, greenhouse gas and waste water (Foster, 1999). Therefore, cities are considered as the main sources of greenhouse gas where urban lifestyles require a large amount of energy. The three-quarters of global pollution is caused mainly by activities predominantly in cities. It has been reported that $75 \%$ of the world's energy is consumed by cities. The growth of a city results in many new multifaceted social, economic and environmental challenges to its residents including reduced greeneries, increased deforestation, vanished water bodies and wetlands, increased pollutions, etc. Especially, the loss of trees and greeneries is manifested by environmental pollution and build-up of urban heat islands escalating the change in global climate and thereby occuring natural disasters (e.g. flood, earthquake, landslide etc.) frequently in recent years. With the purpose of mini- mizing the impacts of climate change and achieving sustainable development, different terms have been proposed after the earth Summit 1992 such as "green urbanism” (Lehmann, 2010), "sustainable cities” (Beatley, 2000), "green cities” (Karlenzig, 2007), “eco-cities” (Lehmann, 2010).

Green urbanism (GU) indicates pollution free future, using public transport, renewable energies, good climatic condition, energy efficient building designs, etc. (Lehmann, 2010). All these issues can be achieved only by provision of greeneries ${ }^{1}$. It can be said that the most important aspect of GU is to provide greeneries inside city spaces which would reduce the unprecedented challenges stated above towards attaining sustainablehealthy-livable (SHL) cities. In this context, an optimal plan for

\footnotetext{
${ }^{1}$ Greeneries can provide good climatic condition by absorbing air pollutants increasing humidity and reducing air temperature, prevent excessive winds and noise, increase water retention and quality, prevent soil errosion, provide shade, protect from sunlight, reduce building energy use, increase aesthetics, decrease occurrence of natural disasters, etc. and thus can improve health of people (Beatley, 2000; Jim, 2004; Adams \& Leedy, 1987; Neema \& Ohgai, 2010; Neema et al., 2008; Neema \& Ohgai, 2013; Godefroid, 2001; Howard, 1902; Kessel et al., 2009; Hillsdon, 2006).
} 
greeneries is expected to minimize many encountered problems of unsustainable, unhealthy, unlivable cities (3U-cities) by reducing pollutants, improving water quality, scaling down energy consumption, improving both physical and mental health of people, reducing urban heat island build-up (Beatley, 2000; Jim, 2004; Adams \& Leedy, 1987; Neema \& Ohgai, 2010; Neema et al., 2008; Neema \& Ohgai, 2013; Godefroid, 2001; Howard, 1902; Amarsaikhan et al., 2006). Figure 1 represents trees are absorbing air pollutants. Therefore, a SHL-city can be achieved if green spaces are provided adequately and sited optimally during both new development and redevelopment of a city. Exuberant urban planning opts to create green cities or garden cities (Howard, 1902; Bradley, 1995).

This research has taken an attempt to present a new GU model based on greeneries for developing SHL-cities. It will also discuss the state-of-the-art of greeneries in Dhaka, prove Dhaka a 3U-city and finally, a greenery-based conceptual model (GBCM) has been proposed to revamp GU in Dhaka to make it a SHL-city. Although Dhaka is facing a number of acute problems such as high population density, high air and water pollution, high air temperature, etc., no systematic study has been reported on GU for developing Dhaka a SHL-city. In this paper, we thus have taken an attempt to provide some scientific judgments on how trees and plantable spaces contribute towards attaining SHL-cities and then index in this context whether Dhaka is SHL-city, and finally the proposed GBCM is evaluated to make Dhaka a SHL-city in foreseeable near future.

The paper is organized in the following ways. First, we provide some criteria of a SHL city in Section 2. In the next Section 2.1, we illustrate GBCM model of green urbanism. In Section 3.1, we describe the present state-of-the-art of greeneries in Dhaka city. Then, in Section 3.2 we briefly summarize the urban environments in Dhaka to justify whether Dhaka is a SHLcity. Next, in section 3.3 we provide some recommendations to make Dhaka a SHL-city. Finally, in Section 4, we draw some concluding remarks.

\section{Methods}

In the study, a SHL-city (sustainable, healthy livable city) is defined as a city which meets the three criteria such as city sustainability, healthy city and livable city. Towards attaining sus-tainable healthy livable (SHL) environment, to develop a greenery-based conceptual model (GBCM), first one may need a clear picture of what do we understand by sustainable, healthy, and livable city (SHL-city).

Sustainable city: A sustainable city is concomitant with the

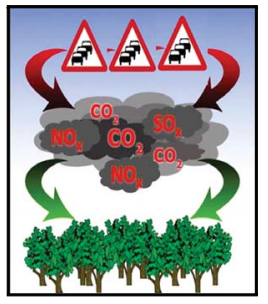

(a)

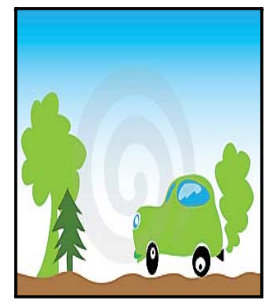

(b)

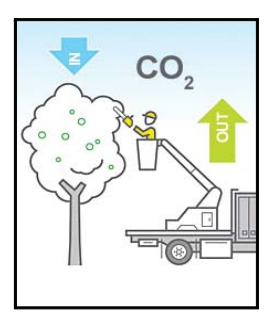

(c)
Figure 1.

(a) Trees absorbing $\mathrm{CO}_{2}, \mathrm{NO}_{x}$ and $\mathrm{SO}_{x}$ ("Carbon-zero-planet Organization”), (b) Trees absorbing emissions generated from cars ("Green Car Vector") and (C) $\mathrm{CO}_{2}$ increasing due to destruction of trees ("Offsetting carbon dioxide"). concept of sustainable development. Sustainable development can be defined as the Development which meets the needs of the present without sacrificing the ability of the future to meet its needs (Nations, 1987). Apart from other criteria such as green transport, sustainable land use, compact development, etc, the most important design criteria for sustainable city is green urbanism.

Urban greeneries and city sustainability are union of each other (Chiesura, 2004; Prescott-Allen, 1991; Ironside, 1999; Campbell, 2001; Beer, 1994).

Healthy city: A healthy city is a healthy place. A healthy city is committed to provide better physical, social and economic environments such as good housing and working conditions, good transportation system, adequate water supply, proper sanitation, better lifestyles and education, health services, nutrition, food safety, population changes, income, and so on (Chiesura, 2004; Szaroa et al., 2000; Hashim \& Kiyu, 1996; Bari \& Efroymson, 2009; Hancock, 1993). Healthy cities thus provide good health and environmental services (WHO, 1996; Baum \& Cooke, 1992; “Towards healthy cities”, 1997). Presumably, people live in healthy cities safely and comfortably (Baum, 1993, 1998). However, with the growth of cities many problems emerge including over population, high-density living, house, and stress. Cities in developing countries lack in resources are confronted with serious consequences from these problems. Healthy condition may break down with tension and stress caused by a number of factors emanated from environment such as overcrowding, high noise levels, and fumes. To create a healthy city, green spaces play the most important role as they provide opportunities for improving health of people. Therefore, any city can take initiative of a healthy city if it rejuvenates with the development and maintenance of physical, social and economic environments which support and promote better health and quality of life for residents (Hancock \& Duhl, 1988; Baum \& Brown, 1989; Ashton, 1993).

Livable city: The idea of livable cities for healthy environment relies mainly on two criteria i.e. first, the basic need is to be fulfilled (i.e. clean air and water, energy and waste management) and second, the quality of life is to be ensured. Adequate greeneries are the most important indicator in achieving the two criteria for making a city livable. However, some predeterminate indicators of the quality of life of city dwellers are security and safety, educational, medical and recreational facilities, environmental friendliness and accessibility to transportation. Due to imposed significant variation of constraints on livable city all over the globe, it is increasingly a challenging task to provide all of these features simultaneously and the most importantly on a sustainable basis.

There are many indicators of achieving a sustainable city, a healthy city and a livable city separately. From the above concept of sustainable-, healthy- and livable-city, it is clear that planting greeneries or greening a city is the common indicator of achieving a sustainable, a healthy and a livable city together. This research thus focused on the common most important indicator of greening city for achieving green urbanism to attain a sustainable healthy livable city together.

\section{GBCM Model of GU}

From the above discussion, it is understood that the first and the most important criteria for a SHL-city is planting of greeneries. Trees can be mimicked as the root of greenery-based 
green urbanism. Thus, planting greeneries wherever space is available is the basis of the conceptual model of green urbanism. There are multivariate beneficial functions of urban greeneries (Mole \& Young, 1992; Godefroid, 1997; Petit et al., 1995). In Figure 2, the multi-function and multi-benefit of greeneries are pictorially represented by a tree, where the multi-function and multi-benefit is realized by multiple leaves of the tree resulting a conceptual model of GU. The idea of GU model is based on making provision for greeneries in all aspects of city planning. Our proposed GBCM Model of GU consists of the followings multiple functions based on benefits bestowed upon humanities from trees and greeneries in general:

1) Improving Soil quality ( $\Psi$ )

2) Providing Foods and Materials for Shelter $(r)$

3) Absorbing UV-rays $(\delta$ )

4) Acting as Barrier to Prevent High Noise $(\zeta)$

5) Absorbing Harmful Air Pollutants $(\rho)$

6) Improving Health of People ( $\rho$ )

7) Offering Opportunities for Recreation $(\chi)$

8) Reducing Air Temperature $(\tau)$

9) Encouraging Walking and Bicycling $(\varsigma)$

10) Acting as Barrier to Prevent High Wind ( $t$ )

11) Protecting Sunlight and Provide Shade $(\vartheta)$

12) Enhancing Aesthetic Scene and City Beauty $(\eta)$

13) Purifying Water resources $(\xi$ )

14) Preventing Ground Water Depletion $(\kappa)$
15) Protecting Biodiversity, Balance Ecosystem $(\lambda)$

If we quantify each benefit using numerical values, we could see the total benefits of greeneries in monetary terms. In this case, we may formulate an equation to calculate the total benefits of a tree and thereby, develop an index of SHL-city as follows (Equation (1)):

where, ISHL = Index for sustainable healthy livable city

where, MVBVT = Multivariate beneficial venture of atree

Green urbanism would undoubtedly play a predominant role for improving health of people. It provides recreation, ensures a good urban climate and relays a basis for a SHL-city (Neema \& Ohgai, 2010; Finco \& Nijkamp, 2003; Mole \& Young, 1992; Johnston, 1990). GU model attempts to address the pressures currently encountering in cities around the globe.

\section{Discussion}

\section{Present State-of-the-Art of Greeneries in Dhaka City}

Dhaka, the capital of Bangladesh, is one of the major megacities of South Asia. The city is located on the bank of the Buriganga River. Including metropolitan area, Dhaka has a population of over 15 million, making it the largest city in Bangladesh. It is the 9th largest city in the world and also fall among the most densely populated cities in the world. Figure 3 shows the

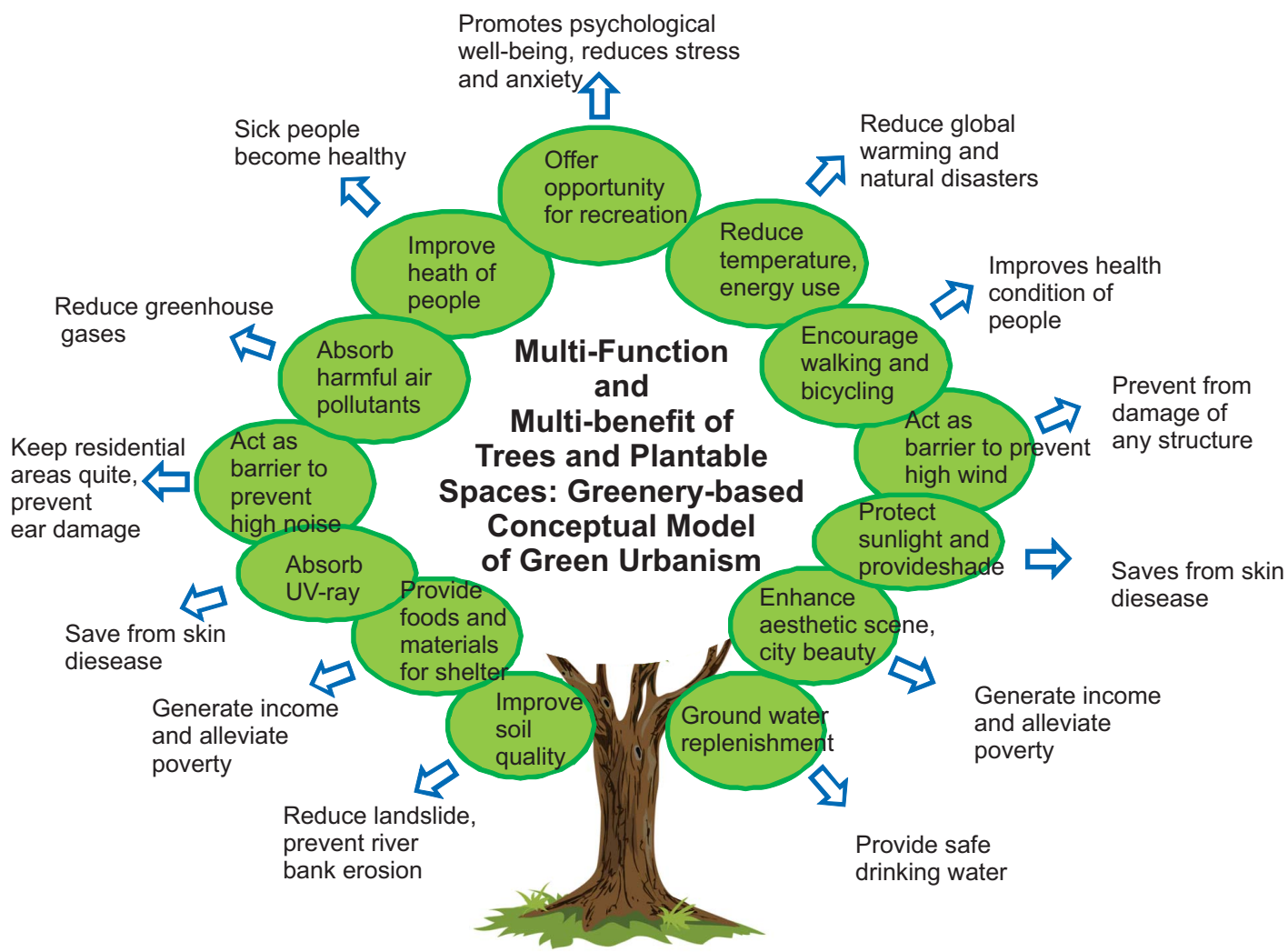

Figure 2.

Multivariate beneficial venture of a tree: A Greenery-Based Model of Green Urbanism.

$$
I S H L=\sum_{i=1}^{v}[M V B V T]=\sum_{i=1}^{v}[\psi+\Upsilon+\delta+\zeta+\rho+\rho+\chi+\tau+\varsigma+\imath+\vartheta+\eta+\xi+\kappa+\lambda]
$$




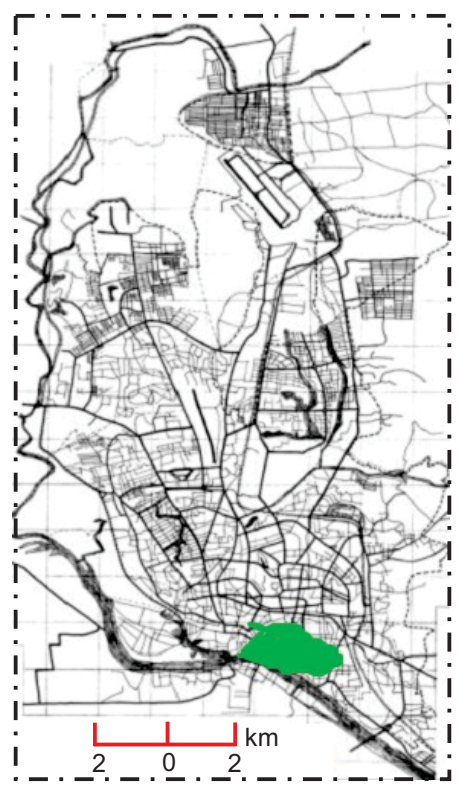

(a)

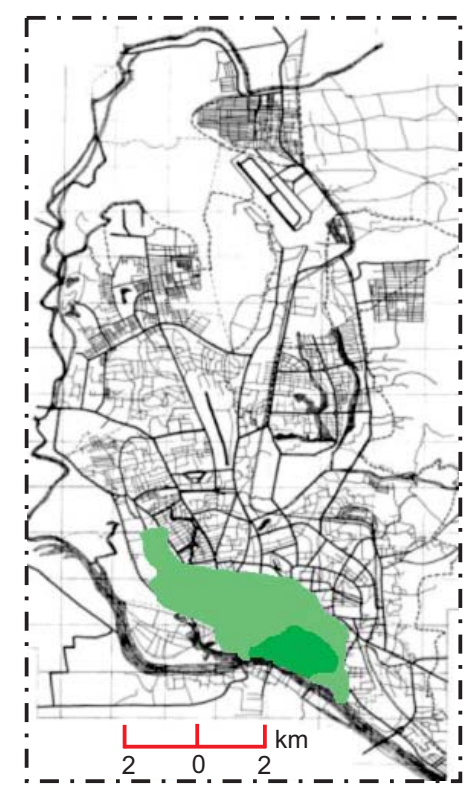

(b)

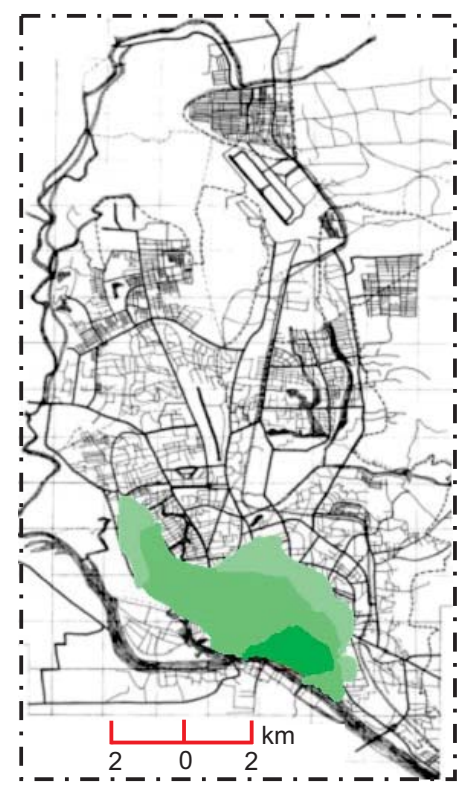

(c)

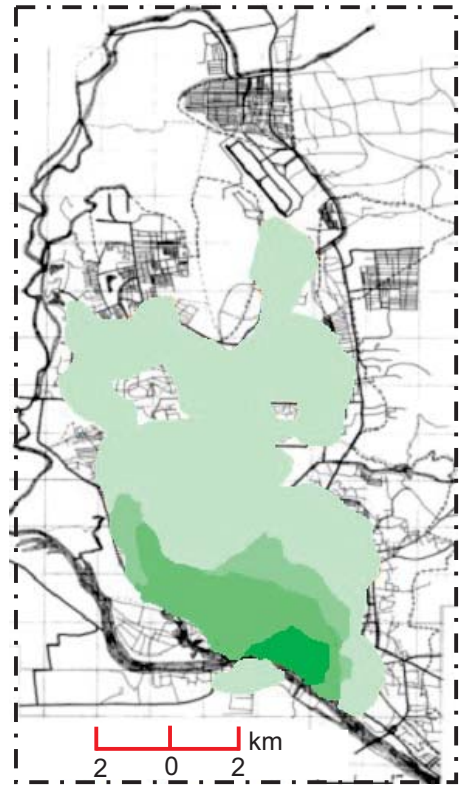

(d)

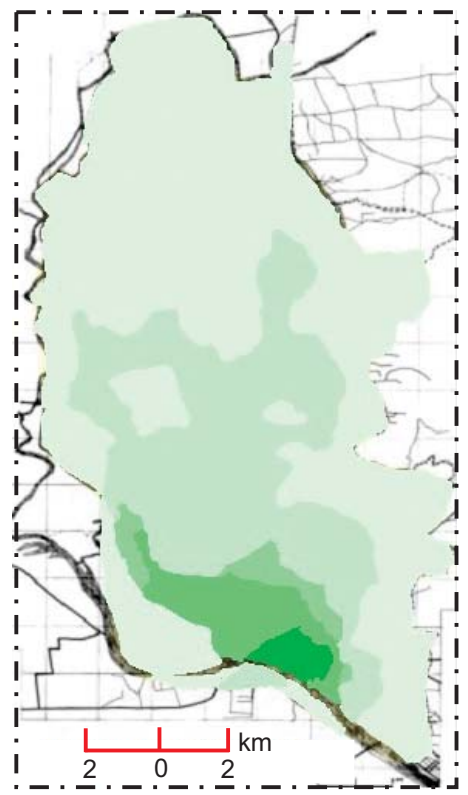

(e)

Figure 3.

Growth and expansion of Dhaka city in the scale of time under five major periods: (a) Pre-Mughal period (before 1604), (b) Mughal period (1604-1764), (c) British period (1764-1947), (d) Pakistan period (1947-1971) and (e) Bangladesh period (after 1971).

growth and expansion of Dhaka city under five major subsequent periods.

Before the merciless urbanization in last three decades, Dhaka was considered as a very fine city with shaded and leafy streets, boats plied in the heart of the city, clean air, promenaded people on the banks of the river, playing children on open fields, and a sense of community among its citizens. Unfortunately, the environment and living condition of the city are deteriorating due to unplanned urbanization, deforestation and haphazard development activity in the city (Neema \& Ohgai, 2010; Neema et al., 2008). In one of our previous research, we analysed the existing conditions of greeneries in Dhaka city. We showed that greeneries in Dhaka are far below the standards followed in different countries in the world (Neema et al., 2008). Moreover, the green spaces are not properly sited. The present state-of-the-art of greeneries in Dhaka city is shown in Figure 4.

\section{Is Dhaka a SHL-City?}

Currently, Dhaka city is heavily burdened with its escalating pollution, widening social inequality, increasing break-down of 
1989

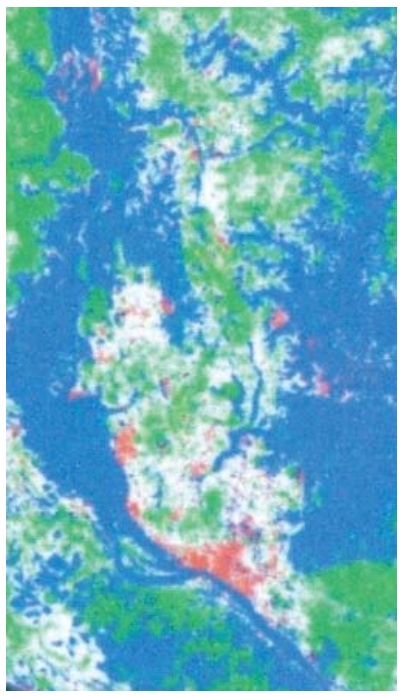

(a)

Greeneries
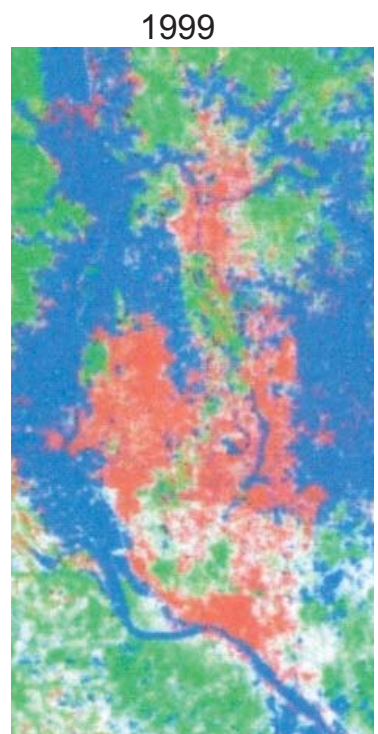

(b)

Wetlands and water bodies

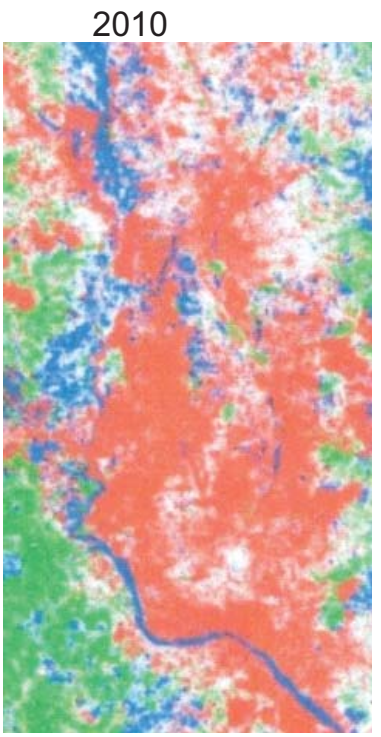

(c)

Built-up areas

Figure 4.

Map showing decreasing rate of green Spaces in Dhaka City during three different periods (Islam et al., 2013): (a) Green spaces in 1989, (b) Green spaces in 1999 and green spaces in 2010.

community, wretched transport and road system, blatant occupation of land and waterways, and ravaging of public spaces. In this context, the city is considered as one of worst living cities in the world. From the ranking of worst living environment in city, Dhaka is in 2nd position (WHO, 2006). The environment of Dhaka city is deteriorating continuously day by day due to unplanned urbanization, destruction of greeneries, deforestation and haphazard development activity in the city and surrounding areas. As all the major economic activities are centralized in Dhaka city, rural-urban migration is naturally increasing at an alarming rate. Compare with the other megacities in the developed world, the present health condition of Dhaka city is very low. The city is over populated and most of the city dwellers reside in unhygienic conditions. The condition of drainage, sewerage, sanitation, garbage disposal is unhealthy in most of the areas in Dhaka city. Besides, there are many slum areas near the roads and rail lines. Traffic congestion is a common daily scenario in the city. Number of cars is increasing day by day which would lead to increasing vehicular emissions Figures 5(a) and (b). The city dwellers suffer from severe pollution like air, water, noise etc. Figure 6 shows existing traffic congestion and severe air pollution in Dhaka city. These are leading to climatic change, which in turn will bring many impacts in the city.

In Bangladesh, rivers are drying up and consequently increasing rainfall causing flood disaster. In addition, groundwater level is dropping down below the sea level, as a result saltwater is entering into the underground vacuum. Figures 5(c) and (d) respectively show groundwater depletion and monsoon rainfall in Dhaka city. Due to deforestation, groundwater level is depleting and there is abrupt change in rainfall in Dhaka city. In near future, these will have serious consequences such as natural disasters.

Moreover, the city does not have adequate greeneries. The high population density in Dhaka makes it environmentally unsuitable to live. Dhaka is confronted with a variety of prob- lems making it a challenging task to revive it as a healthy city. In (Neema \& Ohgai, 2010, 2013), we proposed some optimum sites for providing more parks and open spaces (greeneries) in Dhaka city. However, at present, there is no available space for providing new greeneries in the city and almost all the lands are developed mostly in unplanned way. The city authority at least could adopt our proposed greenery-based conceptual model (GBCM) of green urbanism (GU) to save Dhaka from being unsustainable, unhealthy, and unlivable (3U-city). The idea of "healthy city" has only been recently adopted in developing cities. From 1995 to 1999, the World Health Organization (WHO) supported healthy city projects (HCPs) only in Cox's Bazar city in Bangladesh, Dar es Salaam city in Tanzania, Fayoum city in Egypt, Managua city in Nicaragua and Quetta city in Pakistan. But Dhaka is till lack behind the concept of healthy city. Creation of green oriented Dhaka city may overcome the problems the city is currently facing and thereby transforming it into a healthy livable city. In terms of the vital need, World Health Organization (WHO) recommends 4.23 acres of greeneries per 1000 people. In contrary, the Development Area Plan (DAP) in Dhaka has proposed an insufficient quantity of greeneries ( 0.13 acres for 1000 people), and even has failed to allocate land for them. Meanwhile, Hong Kong, the most crowded city on earth, provides on average 0.71 acres of greeneries per 1000 people, which is more than five times the amount of greeneries proposed by DAP. Moreover, the provision of general public services and social institutions within walking distance of residences is also vital for the development of a lively city. This may reduce traffic congestion and pollution too. Consolidated, regional and larger facilities would create inconvenience for the population and lead to greater congestion and pollution than a more decentralized approach. Therefore, a smart planning is required in order to disintegrate Dhaka City into different functional units (Bari \& Efroymson, 2009). 


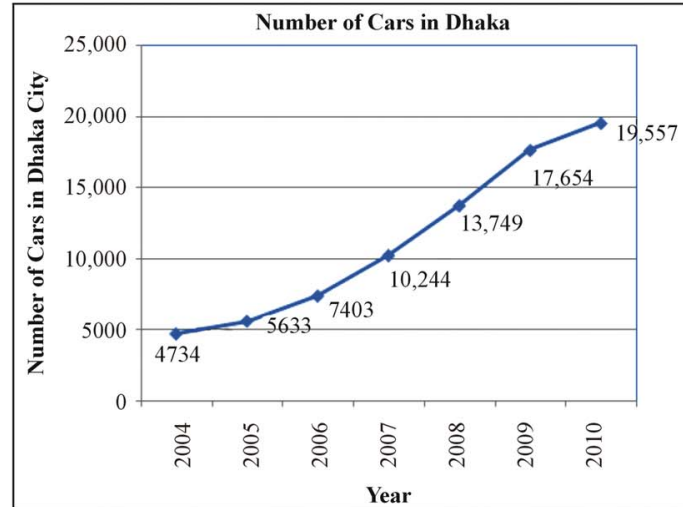

(a)

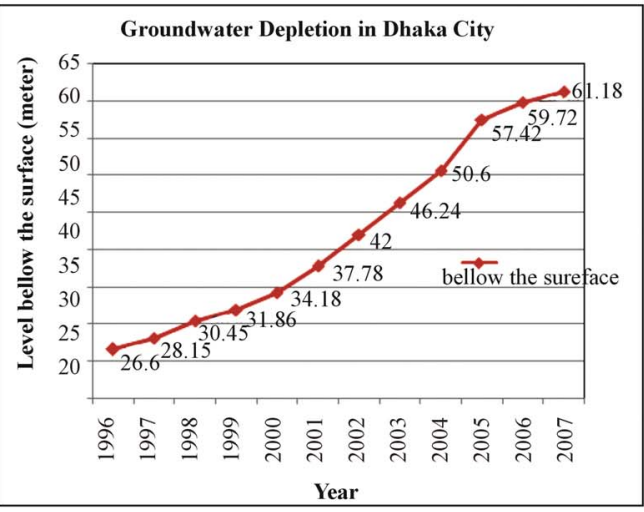

(c)

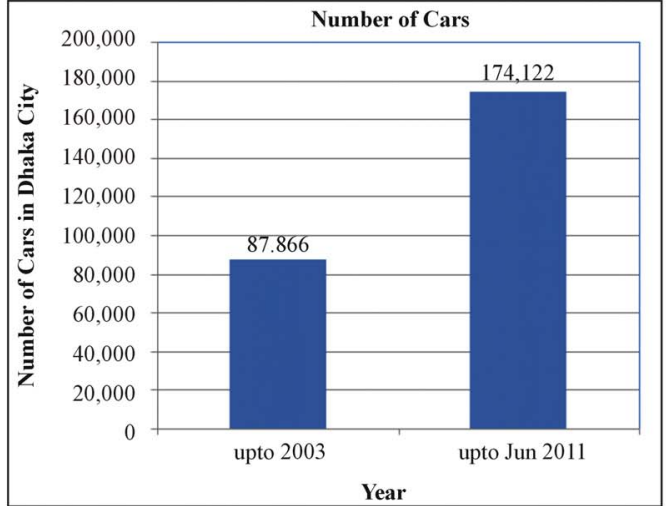

(b)

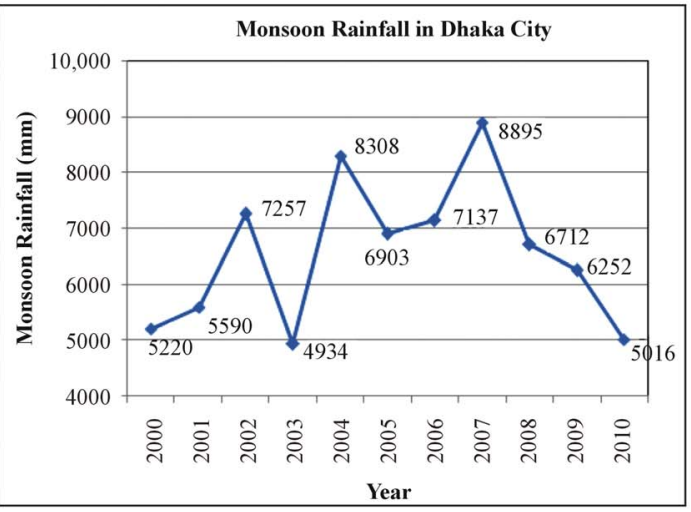

(d)

Figure 5.

(a) Groundwater depletion ("Groundwater monitoring survey project, Bangladesh Agricultural Development Corporation”), (b) Monsoon rainfall in Dhaka city ("Meteorological department of Bangladesh”), (c) Number of cars in Dhaka city (“Road transport authority of Bangladesh”) and (d) Number of cars (“Road transport authority of Bangladesh”).

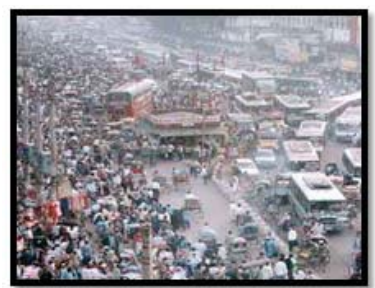

(a)

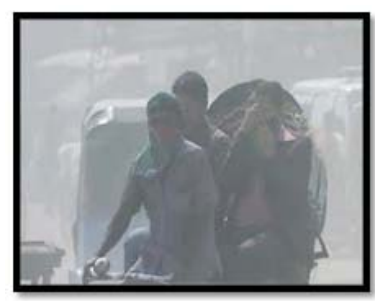

(c)

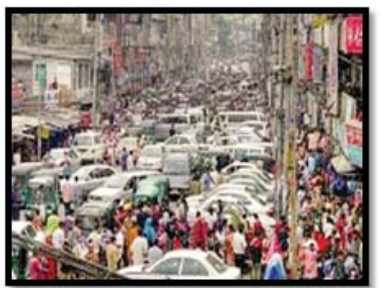

(b)

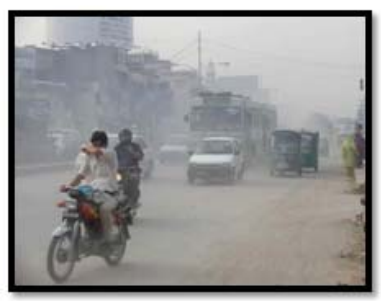

(d)
Figure 6.

(a) Haphazard traffic congestion in an intersection point ("Population growth for a sustainable future"), (b) Severe traffic congestion in front of a shopping centre ("World class traffic jam"), (c) Severe vehicular emission ("Pollution in Dhaka city") and (d) No road side trees to absorb vehicular emission ("Air pollution costs Bangladesh BDT 124 billion”).

\section{A Proposed SHL-City Model for Dhaka}

It is predicted that Dhaka will turn into the 4th largest city in the world by 2015 with about 23 million populations but it will remain as the dirtiest city in the world. As Dhaka city is confronted with numerous problems, to make it a sustainable healthy livable (SHL) city, the topmost priority can be given to green urbanism through the proposed greenery-based conceptual model to make the environment livable. Through the initiation of such a model, the city may be recovered gradually from the unsustainable unhealthy unlivable (3U) situation. If the authority (through city corporations) can aware people properly about importance of greeneries using plantable spaces and trees for our life, Dhaka may revive as a SHL-city within a few years. Figure 7(a) shows the initiatives of the GBCM to adopt GU in Dhaka city. To fulfill all the initiatives within a planned period, the government as well as each citizen would take step in one's own position to make Dhaka a SHL-city. The initiatives of the GBCM are described as follows:

1) First, it is necessary to make provision for trees and greeneries along both sides of road network of Dhaka city. In this case, the size of the trees to be planted will vary according to the hierarchy of roads. For example, by the sides of the primary road, large sized tress like "krishnochura" trees could be planted. This will not only improve living environment but also give an excellent scenic view of Dhaka. Moreover, these trees 


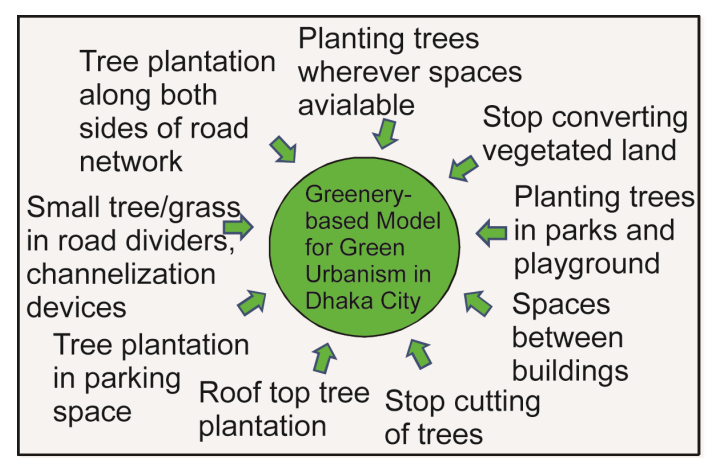

(a)

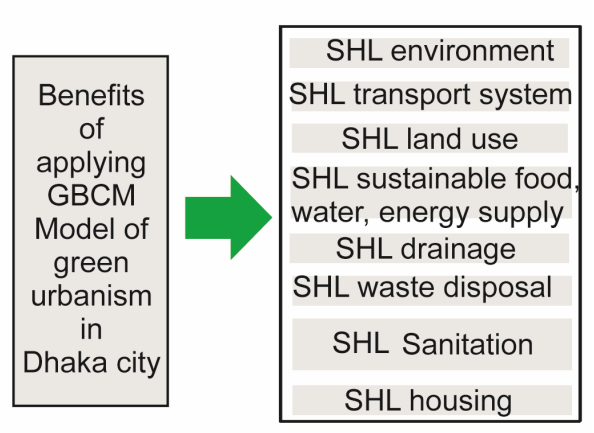

(b)

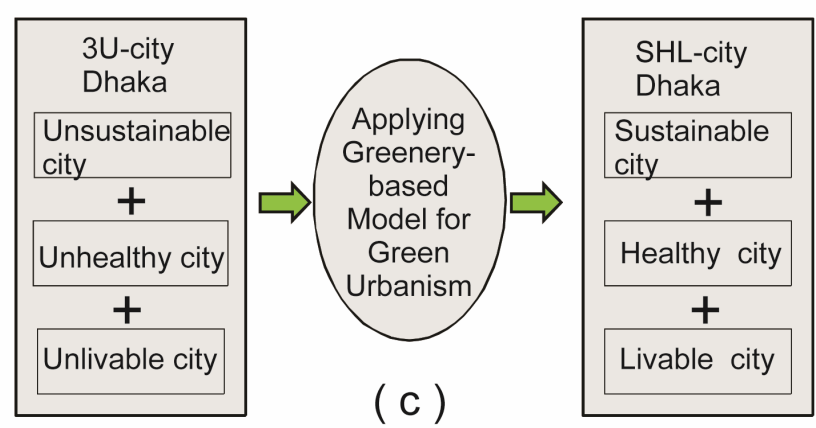

Figure 7.

(a) Steps of GBCM model for GU in Dhaka city (b) Benefits of applying GBCM of GU in Dhaka city and (c) Future Dhaka could be a SHL-city.

could provide shade to the people walk through the footpaths. If the city authority could adopt the first initiative of GBCM, it would be easier to achieve the goal GBCM model.

2) The second initiative is to plant small size trees in road dividers and channelization devices. This will reduce both sound and pollution level of the moving vehicles. This will also give outcome like the first initiatives.

3) It is important to encourage tree plantation in the car parking space, as it could act as a barrier to develop heat-islands.

4) If there is no sufficient space surrounding buildings, a good initiative is to grow flower and vegetable gardens in the rooftops of the buildings. It will give healthy foods as well as keep the buildings comfortable by balancing temperature in summer and winter.

5) This initiative strongly suggests to stop cutting of trees, as it will imbalance climatic condition. If one person cut a tree, he should plant a tree.

6) It is necessary to decorate spaces among buildings by flowering plants. It will improve local climate as well as beauty.

7) If parks and playgrounds do not have adequate greeneries, they will loose their identity. Because if people do not feel better in the park, they will not use it.

8) It is required to stop converting vegetated land uses to other land uses in Dhaka city.

9) If we want to make Dhaka a SHL-city, it is suggested to plant greeneries wherever spaces is available.

However, to make Dhaka a SHL-city GBCM model is required to adopt. Such an approach could ensure the provision of sustainable transport, clean and safe environment, sustainable land use, reliable and sustainable food, water, energy supply, with an effective garbage removal system, healthier sanitation and sewerage systems, sustainable drainage system, etc. Figure 7(b). Sustainable transport can be achieved by planting trees by the side of the roads, inside parking spaces, dividers and channelization devices (implementing initiative 1, 2 and 3). Sustainable environment and land use can be achieved by implementing all the proposed initiatives 1 to 9 .

Then, the implementation of GBCM of GU will transform Dhaka where people will enjoy a SHL-urban lifestyle Figure 7(c). Figure 8 shows few examples of outward looking of a green-city with planting greeneries in roadside space, walls, medians and footpaths in planned cities. We could mimic Dha$\mathrm{ka}$ as a future city with at least planted greeneries like such beauties to revive Dhaka from its severe environmental pollution.

\section{Conclusion}

This paper presents a greenery-based conceptual model for green urbanism. The model can be envisaged as the best, simplest and easiest way of transforming an unsustainable unhealthy unlivable city to a sustainable healthy livable city. It also

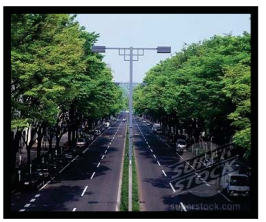

(a)

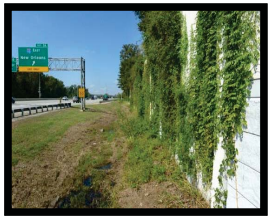

(b)

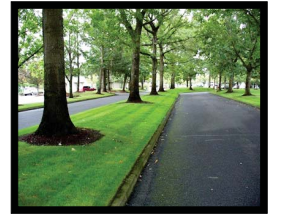

(c)
Figure 8.

(a) Road side trees ("Roadside trees"), (b) Greeneries in road side walls ("Interstate sound walls") and (c) Trees on median and footpaths (“Street images"). 
examines the present living condition of Dhaka city and recommends to revive it as a sustainable healthy livable city in foreseeable days. To make Dhaka a sustainable healthy livable city, it is required to ensure reasonable quality of life, adequate food, shelter, safe drinking water, clean pollution free environment, good transportation, proper utility services, proper education and better economic condition. A considerable part of these basic needs can be provided by implementing greenery-based model for green urbanism. In addition, greeneries in Dhaka can create an ample of opportunities for food production, fodder for livestock, plod for housing, protected watersheds for clean water, sound recreational environments including a variety of entrepreneurial opportunities for employment. Greeneries would provide citizens with aesthetically pleasing work and home environments as well as opportunities for recreation and education thereby improving mental and physical health of citizens. In such a scenario, Dhaka may revive as a green city where the rush for building might consider the foremost need of greeneries at every available nook and corner of the city, where buildings could be mimicked as pavilions in a garden. The greenerybased conceptual model with green urbanism thus can be implemented to secure a healthy sustainable future for the urban populations of Dhaka as well as other cities in Bangladesh.

\section{REFERENCES}

Adams, L. W., \& Leedy, D. L. (1987). Integrating man and nature in the metropolitan environment. Columbia, MD: National Institute for Urban Wildlife.

Air pollution costs Bangladesh BDT 124 billion.

http://respromask.wordpress.com/2012/04/23/air-pollution-costs-bdt124-billion/

Amarsaikhan, D., Ganzorig, M., Moon, T., Lhavgajav, T., Gantuya, I., \& Tsogzol, G. (2006) Evaluation of urbanization process in ulaanbaater city using multitemporal RS images.

http://a-a-r-s.org/acrs/proceeding/ACRS2006/Papers/C-1 C4.pdf

Ashton, J. (1993). Healthy cities. Milton Keyes, PA: Open University Press.

Bari, M., \& Efroymson, D. (2009). Detailed area plan DAP for Dhaka metropolitan development plan DMDP: A critical review.

Baum, F. (1993). Healthy cities and change: Social movement or bureaucratic tool? Health Promotion International, 8, 31-40. doi:10.1093/heapro/8.1.31

Baum, F. (1998). The new public health: An Australian perspective. Part 7 Melbourne: Oxford University Press.

Baum, F., \& Brown, V. (1989). Healthy cities (Australia) project: Issues of evaluation for the new public health. Community Health Studies, 13, 140-149. doi:10.1111/j.1753-6405.1989.tb00190.x

Baum, F., \& Cooke, R. (1992). Healthy cities australia: The evaluation of the pilot project in noarlunga, South Australia. Health Promotion International, 7, 181-193. doi:10.1093/heapro/7.3.181

Beatley, T. (2000). Green urbanism: Learning from European cities. Washington DC: Island Press.

Beer, A. (1994). Urban greenspace and sustainability. In van der Vegt, et al. (Eds.), Proceedings of a PRO/ECE-workshop on sustainable urban development: Research and experiments, Dordrecht.

Bradley, G. (1995). Urban forest landscapes: Integrating multidisciplinary perspectives. Seattle, WA: University of Washington Press.

Campbell, K. (2001). Rethinking open space, open space provision and management: A way forward, report presented by Scottish executive central research unit, Edinburgh.

Carbon-Zero-Planet Organization (2013).

http://www.carbonzeroplanet.org/education/co2cycle.php

Chiesura, A. (2004). The role of urban parks for the sustainable city. Landscape and Urban Planning, 68, 129-138.

doi:10.1016/j.landurbplan.2003.08.003
Finco, A., \& Nijkamp, P. (2003). Pathways to urban sustainability. Journal of Environmental Policy and Planning, 3, 289-302. doi:10.1002/jepp.94

Foster, J. B. (1999). Marx0s theory of the metabolic rift: Classical foundations for environmental sociology. American Journal of Sociology, 105, 366-405. doi:10.1086/210315

Godefroid, S. (1997). Quantifying urban forest structure, function, and value, the chicago urban forest climate project. Urban Ecosystems, 1, 49-61. doi:10.1023/A:1014350822458

Godefroid, S. (2001). Temporal analysis of the brussels flora as indicator for changing environmental quality. Landscape and Urban Planning, 52, 203-224. doi:10.1016/S0169-2046(00)00117-1

Green Car Vector (2013).

http://www.allfreelogo.com/rf-vector/8477198-green-car-vector.html

Groundwater monitoring survey project, Bangladesh Agricultural Development Corporation (2013). http://www.badc.gov.bd/

Hancock, T. (1993). The evolution, impact, and significance of the healthy cities/ healthy community movement. Journal of public health policy, 14, 5-18. doi:10.2307/3342823

Hancock, T., \& Duhl, L. (1988). Promoting health in the urban context. WHO Healthy Cities Papers, 1.

Hashim, J., \& Kiyu, A. (1996). Pathways to healthy city Kuching. Copenhagen: Malaysian Medical Association Annual Magazine, Regional Office for Europe.

Hillsdon, M. (2006). The relationship between access and quality of urban green space with population physical activity. Public Health, 120, 1127-1132. doi:10.1016/j.puhe.2006.10.007

Howard, E. (1902). Garden cities of tomorrow. London: Faber and Faber.

Interstate sound walls (2013).

http://theadvocate.com/columnists/4050719-55/ask-the-advocate-inte rstate-sound

Ironside, F. (1999). Quality green space for residential areas. Perth: $\mathrm{SNH}$.

Islam, S., Ayaon, B., \& Shubho, T. (2013). Land use change outside DMDP area: Study of trend associated issues and permission process. Undergraduate Thesis, Dhaka: Department of Urban and Regional Planning, Bangladesh University of Engineering and Technology.

Jim, C. Y. (2004). Green-space preservation and allocation for sustainable greening of compact cities. Cities, 21, 311-320. doi:10.1016/j.cities.2004.04.004

Johnston, J. (1990). Nature areas for city people. Ecology handbook, London: London Ecology Unit.

Karlenzig, W. (2007). How green is your city? Gabriola Island, British Columbia: New Society Publishers.

Kessel, A., Green, J., Pinder, R., Wilkinson, P., Grundy, C., \& Lachowycz, K. (2009). Multidisciplinary research in public health: A case study of research on access to green space. Public Health, 123, 3238. doi:10.1016/j.puhe.2008.08.005

Lehmann, S. (2010). The principles of green urbanism: Transforming the city for sustainability. London: Earthscan.

Meteorological Department of Bangldesh (2013). http://www.bmd.gov.bd/

Mole, G., \& Young, S. (1992). Growing greener cities: A tree planting handbook. Los Angeles, CA: Living Planet Press.

Nations, U. (1987). Report of the world commission on environment and development.

General Assembly Resolution (1987).

Neema, M., \& Ohgai, A. (2010). Multi-objective location modeling of urban parks and open spaces: Continuous optimization. Computers, Environment and Urban Systems, 34, 359-376. doi:10.1016/j.compenvurbsys.2010.03.001

Neema, M., \& Ohgai, A. (2013). Multitype green-space modeling for urban planning using GA and GIS. Environment and Planning B: Planning and Design, 40, 447-473. doi:10.1068/b38003

Neema, M., Ohgai, A., \& Emanuel, L. (2008). Analyzing existing condition and location of open spaces in Dhaka city. Proceedings of 6th Int. Symposium on City Planning and Urban Management in Asian Countries, Jinju.

Offsetting carbon dioxide (2013). 


\section{N. NEEMA ET AL.}

http://money.cnn.com/galleries/2010/technology/1003/gallery.green myths.fortune/16.html

Petit, J., Bassert, D., \& Kollin, C. (1995). Building greener neighborhoods: Trees as part of the plan. Washington DC: American Forestry Association.

Pollution in Dhaka City (2013).

http://pollutionindhakacity.weebly.com/air-pollution.html

Population growth for a sustainable future (2013).

http://blogs.worldwatch.org/sustainableprosperity/robert-engleman-d iscussespopulation-and-a-sustainable-future

Prescott-Allen, R. (1991). Caring for the earth: A strategy for sustainable living, IUCN, The World Conservation Union, United Nation Environmental Program, Worldwide Fund for Nature. Gland.

Road transport authority of Bangladesh (2013).

http://www.brta.gov.bd/

Roadside trees (2013) http://www.superstock.com/stock-photos-images/4034-92051

Street images (USA) (2013). http://gophoto.us/key/streets

Szaroa, R., Langora, D., \& Yapib, A. (2000). Sustainable forest management in the developing world: Science challenges and contributions. Landscape and Urban Planning, 47, 135-142. doi:10.1016/S0169-2046(99)00082-1

Towards Healthy Cities (1997). Proceedings of the International Conference on Healthy Cities. Beijing: Beijing Municipal Health Bureau.

WHO (1996). City health planning: The framework. Copenhagen: World Health Organization, Regional Office for Europe.

WHO (2006). WHO air quality guidelines for particulate matter, ozone, nitrogen dioxide and sulfur dioxide, global update 2005. Summary of Risk Assessment, Geneva: WHO Press.

World Class Traffic Jam (2013).

http://www.flickr.com/photos/joiseyshowaa/2402764792/ 